\title{
THE
}

1995

\section{Differences in Wintering Areas of Snowy Plovers From Inland Breeding Sites in Western North America}

Gary W. Page

Mark A. Stern

Peter W. C. Paton

University of Rhode Island, ppaton@uri.edu

Follow this and additional works at: https://digitalcommons.uri.edu/nrs_facpubs

Part of the Environmental Sciences Commons, and the Ornithology Commons

Terms of Use

All rights reserved under copyright.

\section{Citation/Publisher Attribution}

Page, G., Stern, M., \& Peter W. C. Paton. (1995). Differences in Wintering Areas of Snowy Plovers from Inland Breeding Sites in Western North America. The Condor, 97(1), 258-262. doi:10.2307/1369001 Available at: http://dx.doi.org/10.2307/1369001

This Article is brought to you for free and open access by the Natural Resources Science at DigitalCommons@URI. It has been accepted for inclusion in Natural Resources Science Faculty Publications by an authorized administrator of DigitalCommons@URI. For more information, please contact digitalcommons-group@uri.edu. 


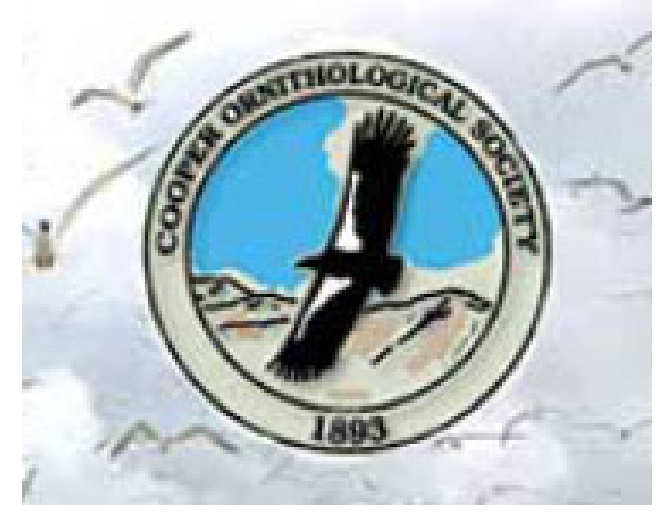

Differences in Wintering Areas of Snowy Plovers from Inland Breeding Sites in Western North America

Author(s): Gary W. Page, Mark A. Stern and Peter W. C. Paton

Reviewed work(s):

Source: The Condor, Vol. 97, No. 1 (Feb., 1995), pp. 258-262

Published by: University of California Press on behalf of the Cooper Ornithological Society

Stable URL: http://www.jstor.org/stable/1369001

Accessed: 16/07/2012 15:09

Your use of the JSTOR archive indicates your acceptance of the Terms \& Conditions of Use, available at http://www.jstor.org/page/info/about/policies/terms.jsp

JSTOR is a not-for-profit service that helps scholars, researchers, and students discover, use, and build upon a wide range of content in a trusted digital archive. We use information technology and tools to increase productivity and facilitate new forms of scholarship. For more information about JSTOR, please contact support@ jstor.org.

University of California Press and Cooper Ornithological Society are collaborating with JSTOR to digitize, preserve and extend access to The Condor. 


\title{
DIFFERENCES IN WINTERING AREAS OF SNOWY PLOVERS FROM INLAND BREEDING SITES IN WESTERN NORTH AMERICA ${ }^{1}$
}

\author{
Gary W. Page \\ Point Reyes Bird Observatory, 4990 Shoreline Hwy., Stinson Beach, CA 94970
}

\author{
MARK A. STERN \\ The Oregon Natural Heritage Program, 1205 NW 25th Street, Portland, OR 97210 \\ Peter W. C. Paton \\ Utah Cooperative Fish and Wildlife Research Unit, Department of Fisheries and Wildlife, \\ Utah State University, Logan, UT 84322
}

Key words: Charadrius alexandrinus; wintering areas; differential migration; Snowy Plover.

West of the Rocky Mountain/Sierra Madre Cordillera, Snowy Plovers (Charadrius alexandrinus) breed along the Pacific coast from southern Washington to southern Baja California and inland from eastern Oregon and northern Utah south into the interior of Mexico (AOU 1983, Page et al. 1991, Howell and Webb 1994). Except for agricultural evaporation ponds in the southern San Joaquin Valley and a few locations in the deserts of southern California (particularly the Salton Sea), inland areas in the western United States are abandoned for the winter (Page et al. 1986). Wintering areas of the inland breeders should lie within the species' western winter range which extends primarily along the Pacific coast from northern Oregon to southern Mexico, where the species is common, and south to Panama, where it is reportedly uncommon (AOU 1983, Castro and Myers 1988). Evidence of the movement of color-banded Snowy Plovers from one inland breeding location, Mono Lake, to wintering locations along the Pacific coast of California and Baja California is documented in Page et al. (1986).

During the late 1980s and early 1990s several hundred Snowy Plovers were banded at three inland breeding sites in western North America. Enough of these plovers have been located on the wintering grounds to test whether birds from different inland breeding localities segregate geographically on the wintering grounds. Sufficient numbers of breeding birds from one site were also located to test whether birds of differing age or gender also varied in choice of wintering areas.

\section{STUDY AREAS AND METHODS}

During the period 1988-1992 a total of 522 adult and 506 chick or juvenile (hereafter immature) Snowy Plovers were color banded at three interior breeding sites in western North America (Table 1). Marked birds included adults and immatures at two Great Basin sites (Lake Abert, Oregon and Great Salt Lake, Utah). Only

1 Received 14 March 1994. Accepted 21 September 1994. immature birds were banded at the third location, a number of agricultural waste water ponds in the southern San Joaquin Valley of California. At the two Great Basin sites adults were marked with unique combinations of 3-4 color bands. Immature birds were banded similarly, except for the color coding, which was usually by brood rather than by individual. All chicks from the San Joaquin Valley were marked with a single white color band on one leg.

Searches were conducted for these birds by a network of volunteers that visited coastal California beaches and salt ponds as frequently as once a month from August to April to count plovers and look for marked birds. The proportion of these coastal wintering areas covered by the volunteer network during five consecutive winters, from 1988 to 1992 , ranged from $52-67 \%$ $(\bar{x}=59 \%, \mathrm{SD}=7)$ of the 141 potential sites identified since 1979 (PRBO, unpubl. data). Cumulatively, about $80 \%$ of all sites were covered over the five-winter period. While this survey did not extend into Baja California, one of us searched for marked plovers on beaches at La Mission and Bahia San Quintin, and on tidal flats at Ojo de Liebre on the west Baja coast from 4-9 January 1991; at four beaches between Loreto and Mulege on the east coast from 20-21 January 1992; and at nine beaches from Las Barrancas to La Salina on the west coast from 19-28 January 1992. P. Ashfield and $M$. Jungers searched 11 beaches on the west Baja coast between the United States/Mexico border and Bahia San Quintin from January to February 1989. Other persons studying shorebirds in Baja between 1989 and 1993 were also alerted to look for color-banded plovers. The only other Mexican locations searched by one of us were beaches in the Puerto Penasco and El Gulfo de Santa Clara regions of Sonora State, in March, September and December 1991, and December 1992. The Oregon coast was surveyed at least once annually during winter by workers of the Oregon Department of Fish and Wildlife.

Any marked Snowy Plover located on the coast between 15 October and 10 March was considered to be at its wintering area. Any sighted between 1 July and 14 October was considered a potential fall migrant and any between 11 March and 30 April a potential spring migrant. 


\section{RESULTS}

During the study $20.5 \%$ of 166 marked adults from Lake Abert were located during winter. This was a significantly larger proportion than the $0.6 \%$ of 356 marked adults located from Great Salt Lake (Table 1, $\left.\chi^{2}=69.96, P<0.0001\right)$. The proportion of immature birds found during winter was also much greater for the Lake Abert than the Great Salt Lake cohort (Table 1), but we did not test the difference because of the potential confounding effect of fledgling survival rates, which may vary considerably among locations (PRBO, unpubl. data).

All 54 marked birds from Lake Abert, found during winter, were on either the coast of California or the west coast of Baja California (Fig. 1, Table 2). In contrast, no birds from Great Salt Lake were found in California and only one was located on the Pacific coast of Baja. The remaining three birds from Great Salt Lake were found in the Gulf of California (Fig. 1, Table 2). There were no sightings of additional Great Salt Lake birds during migration.

During the study $16.4 \%$ of the males, $23.7 \%$ of the females and $9.8 \%$ of the immatures banded at Lake Abert were located in winter. Detection rates of males and females were not significantly different $\left(\chi^{2}=1.3\right.$, $P=0.25)$. Nor did the latitudes of wintering areas differ significantly with age or gender (Fig. 1, Kruskal-Wallis Test, $P=0.71)$. The most northerly wintering areas of each age and sex class were all in California and the most southerly areas in southern California or Baja California (Fig. 1). The straight line distance between the most northerly and southerly wintering areas of the Lake Abert birds was $1,970 \mathrm{~km}$. Median wintering locations for each sex and age class all fell within the 80-km distance between Toro Creek, San Luis Obispo County and the Santa Ynez River mouth, Santa Barbara County, California. Of the Lake Abert birds whose wintering areas were discovered, $67 \%$ of the males, $73 \%$ of the females and $60 \%$ of the immatures were seen at their winter locations in at least two years, and $33 \%$ of the males, $32 \%$ of the females, and $35 \%$ of the immatures for at least three years.

In addition to the 54 Lake Abert birds located during winter, there were nine (three immature, three male, three female) Lake Abert birds that may have been migrating when sighted. One was reported from the Oregon coast, seven from the California or Baja coasts within the range reported for wintering birds, and one, identified as a female, was located south of all other Lake Abert birds at Bahia Santa Maria, Baja Sur (Fig. 1). One additional bird, an immature from Lake Abert, was seen on the California coast at Monterey Bay, on 4 June 1990, at a time when most plovers are breeding. This bird, identified as a male, was only seen once in an area that was monitored closely for breeding Snowy Plovers. There was no indication it attempted to breed there.

The five immatures banded in the San Joaquin Valley were all in coastal California in winter (Table 2). In contrast to the birds banded at all the other breeding areas, three of five San Joaquin Valley birds wintered north of their natal areas (Fig. 1).

Banding data from two other inland breeding sites indicate movement of Snowy Plovers to the coast for

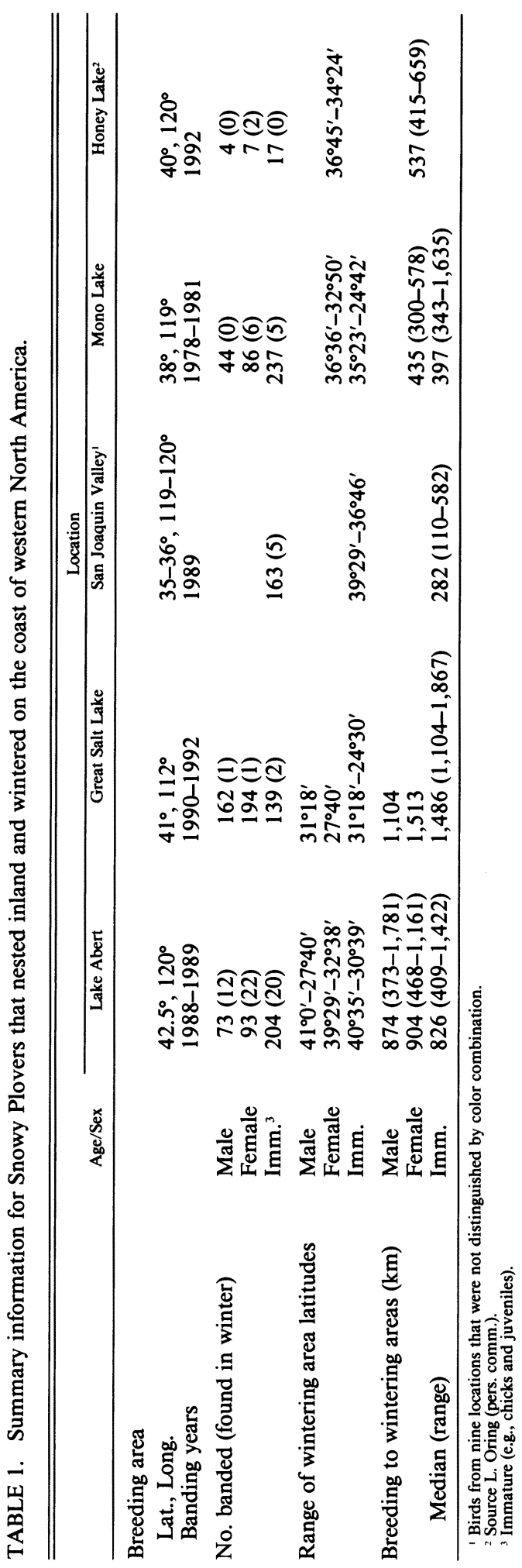



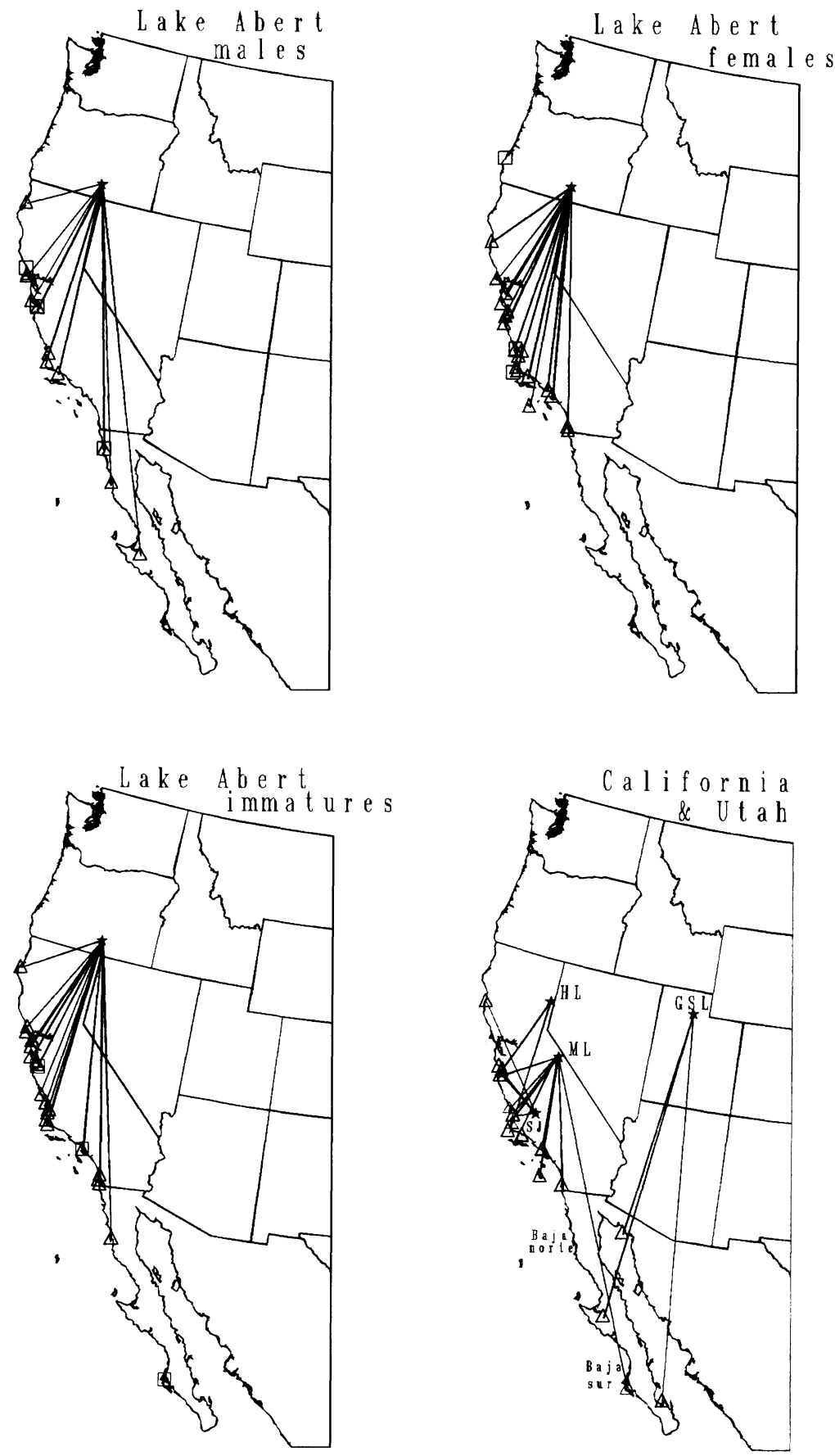

FIGURE 1. Winter locations of Snowy Plovers banded during summer at three inland study sites in western North America: Lake Abert, Oregon; Great Salt Lake, Utah (GSL); and the San Joaquin Valley, California (SJ). Triangles are for plovers seen in winter, and squares for birds seen during migration. Also included are records of birds from other studies: ML for Mono Lake, California (Page et al. 1986) and HL for Honey Lake, California (L. Oring, pers. comm.). 
TABLE 2. Winter locations of Snowy Plovers from inland breeding areas in western North America.

\begin{tabular}{|c|c|c|c|c|c|}
\hline Breeding site & Wintering site & Male & Female & $\underset{\text { mature }}{\text { Im- }}$ & $\begin{array}{c}\text { Approx- } \\
\text { imate } \\
\text { distance } \\
\text { moved (km) }\end{array}$ \\
\hline Great Salt Lake, Utah & Puerto Penasco, Mexico & 1 & & 1 & 1,100 \\
\hline Great Salt Lake, Utah & Guerrero Negro, Baja Sur, Mexico & & 1 & & 1,510 \\
\hline Great Salt Lake, Utah & Isla Espirito Santo, Baja Sur, Mexico & & & 1 & 1,870 \\
\hline Lake Abert, Oregon & Bandon Beach, Oregon & & 1 & & 350 \\
\hline Lake Abert, Oregon & Eel River, California & 1 & & 1 & 373 \\
\hline Lake Abert, Oregon & MacKerricher Beach, California & & 1 & & 470 \\
\hline Lake Abert, Oregon & Doran Beach, California & 1 & & & 550 \\
\hline Lake Abert, Oregon & Point Reyes, California & 2 & 1 & 2 & 570 \\
\hline Lake Abert, Oregon & San Francisco Bay, California & & 1 & 1 & 610 \\
\hline Lake Abert, Oregon & Santa Cruz County, California & 3 & 1 & 4 & 660 \\
\hline Lake Abert, Oregon & Monterey County, California & & 5 & 1 & 690 \\
\hline Lake Abert, Oregon & Arroyo Laguna, California & & & 1 & 800 \\
\hline Lake Abert, Oregon & Morro Bay, California & & 2 & 2 & 830 \\
\hline Lake Abert, Oregon & Pt. San Luis-Pt. Sal, California & 1 & 1 & 2 & 850 \\
\hline Lake Abert, Oregon & Pt. Sal-Pt. Conception, California & 1 & 2 & 2 & 890 \\
\hline Lake Abert, Oregon & Devereaux Slough, California & 1 & 3 & 1 & 930 \\
\hline Lake Abert, Oregon & Malibu, California & & 1 & & 980 \\
\hline Lake Abert, Oregon & Hermosa Beach, California & & 1 & 2 & 1,000 \\
\hline Lake Abert, Oregon & San Nicolas Island, California & & 2 & & 1,065 \\
\hline Lake Abert, Oregon & San Diego County, California & & 2 & 3 & 1,150 \\
\hline Lake Abert, Oregon & Estero Beach, Baja Norte, Mexico & 2 & & & 1,270 \\
\hline Lake Abert, Oregon & San Quintin Bay, Baja Norte,Mexico & 2 & & 1 & 1,429 \\
\hline Lake Abert, Oregon & Guerrero Negro, Baja Sur, Mexico & 1 & & & 1,781 \\
\hline Lake Abert, Oregon & Bahia Santa Maria, Baja Sur, Mexico & & & 1 & 2,100 \\
\hline San Joaquin Valley, California & MacKerricher Beach, California & & & 1 & 580 \\
\hline San Joaquin Valley, California & Wilder Beach, California & & & 1 & 282 \\
\hline San Joaquin Valley, California & Sunset Beach, California & & & 1 & 260 \\
\hline San Joaquin Valley, California & Pt. San Luis-Pt. Sal, California & & & 1 & 110 \\
\hline San Joaquin Valley, California & San Diego County, California & & & 1 & 370 \\
\hline Mono Lake, California & Del Monte Beach, California & & & 1 & 300 \\
\hline Mono Lake, California & Atascadero Beach, California & & & 1 & 340 \\
\hline Mono Lake, California & Pt. San Luis-Pt. Sal, California & & & 1 & 360 \\
\hline Mono Lake, California & Pt. Sal-Pt. Conception, California & & & 2 & 400 \\
\hline Mono Lake, California & Devereaux Beach, California & & 2 & & 420 \\
\hline Mono Lake, California & Malibu Lagoon, California & & 2 & & 450 \\
\hline Mono Lake, California & San Clemente Island, California & & 1 & & 580 \\
\hline Mono Lake, California & Magdalena Bay, Baja Sur, Mexico & & & 1 & 1,635 \\
\hline Honey Lake, California & Elkhorn Slough, California & & 1 & & 415 \\
\hline Honey Lake, California & Santa Barbara Harbor, California & & 1 & & 660 \\
\hline
\end{tabular}

winter. Birds banded at Mono Lake, California were located between southern Monterey Bay, California and Magdalena Bay, Baja Sur, Mexico (Fig. 1, Table 2, Page et al. 1986). We also found two Snowy Plovers banded at Honey Lake, California by L. Oring (pers. comm.) on the California coast (Fig. 1, Table 2).

\section{DISCUSSION}

Our study did not reveal any significant differences in wintering areas related to age or gender. There was no evidence that males and females from Lake Abert wintered in separate areas. Although the probability of sighting males and females from Mono Lake during the winter appeared to be different (Table $1, P=0.08$, Fisher Exact Test), the small number of wintering birds that were located limited the power of the statistical test; this made it impossible to draw a meaningful biological conclusion concerning the geographic separation of males and females from Mono Lake in winter.

We found that Snowy Plovers from breeding areas in the interior of western North America winter along the Pacific coast and in the Gulf of California. Birds from Lake Abert, Oregon were found in winter months along the Pacific coast from northern California south to Guerrero Negro, Baja Sur, Mexico. In contrast, no adult or immature birds banded at Great Salt Lake, Utah were located in California or in Baja Norte despite an extensive search effort. Our limited data suggest the Gulf of California coastline and the west coast of Baja Sur are the primary wintering areas for birds breeding in northern Utah.

We cannot explain the absence of birds from Great 
Salt Lake along the California coast during winter. Distance is eliminated as a factor. It is about $970 \mathrm{~km}$ from Great Salt Lake to the central California coast (San Francisco Bay) and $1,100 \mathrm{~km}$ to the southern California coast (Santa Barbara) whereas the closest documented wintering area of a Great Salt Lake breeder was 1,104 km away (Table 1).

Only $20 \%$ of the breeding birds banded at Lake Abert were located on the heavily-searched coastline of California and on the reasonably well surveyed coast of Baja Norte. However, some wintering birds from Lake Abert were undoubtedly missed in California and western Baja, as corroborated by the sighting of nine birds only during migration periods. While no breeding birds from Lake Abert were located on either coast of the Gulf of California (Fig. 1), some may winter there. We surveyed a very limited amount of the potential wintering habitat in the Gulf of California. If distance were a primary factor in selection of wintering areas, the winter range we report for birds from western Great Basin breeding sites would be the most logical since it is further to the closest Gulf of California wintering area (Lake Abert, 1,269 km; Honey Lake, 1,060 km; Mono Lake, $800 \mathrm{~km}$ ) than to coastal wintering locations in California (Table 2).

Snowy Plovers also breed inland east of the Rocky Mountains on the southern Great Plains (AOU 1983). Little is known about the wintering range of these birds. Two banded plovers from Kansas have been sighted on the Texas coast in winter (R. Boyd, pers. comm.); however, it is not known whether some breeders from the southern Great Plains also migrate to the Gulf of California or Pacific coast for winter. Further investigation of banded or radio-tagged birds will also be necessary to determine if birds from inland breeding sites west of the Rocky Mountains move as far east as the Gulf of Mexico coast for winter.

We thank the many people who searched for colorbanded Snowy Plovers during winter and Frances Bidstrup for coordinating their efforts. L. Oring kindly provided information on Snowy Plovers from Honey Lake. L. Stenzel assisted with statistical analysis. The Utah Division of Wildlife Resources, Native Wildlife Section, provided funding for Peter Paton's fieldwork. Funding for work in Oregon was provided by the Oregon Department of Fish and Wildlife Nongame Program and the Bureau of Land Management, Lakeview District.

\section{LITERATURE CITED}

American Ornithologists' Union. 1983. Checklist of North American birds. Allen Press, Lawrence, $\mathrm{KS}$.

Castro, G., AND J. P. Myers. 1988. Snowy Plover (Charadrius alexandrinus) records from Panama. Am. Birds 42:374.

HOWELL, S.N.G., AND S. WEBB. 1994. Occurrence of Snowy and Collared Plovers in the interior of Mexico. West. Birds 25:146-150.

Page, G. W., F. C. Bidstrup, R. J. Ramer, AND L. E. STENZEL. 1986. Distribution of wintering Snowy Plovers in California and adjacent states. West. Birds 17:145-170.

Page, G. W., L. E. Stenzel, W. D. Shuford, and C. R. BRUCE. 1991. Distribution and abundance of the Snowy Plover on its western North American breeding grounds. J. Field Ornithol. 62:245-255. 